\title{
Urgensi Penerapan Interdependent Airspace Governance Untuk Optimalisasi Tata Kelola Ruang Udara Nasional Sebagai Antisipasi Open Sky Policy
}

\author{
Wahyu Beny Mukti Setiyawan ${ }^{1 *}$, Nurul Hidayah ${ }^{2}$, Andi Chaerul Sofyan ${ }^{3}$ \\ ${ }^{1,2}$ Fakultas Hukum Universitas Islam Batik Surakarta \\ ${ }^{3}$ Fakultas Hukum Universitas Sebelas Maret \\ *Correspondence Email: muktibeny@gmail.com; contact.nurulhidayah@gmail.com; andichaerulsofyan@student.uns.ac.id
}

\begin{abstract}
Abstrak. Indonesia sebagai negara kepulauan (archipelago state) memiliki ruang udara nasional seluas $5.180 .053 \mathrm{~km}^{2}$. Ruang udara Indonesia terletak pada posisi yang strategis di antara benua Asia dan Australia yang membuat Indonesia sebagai salah satu jalur lintas penerbangan terpadat didunia. ${ }^{1}$ Oleh karena itu, pengelolaan ruang udara merupakan hal vital yang harus ditegaskan melalui berbagai instrumen hukum. Kedaulatan ruang udara Indonesia ditegaskan di dalam Pasal 49 ayat (2) Konvensi Hukum Laut Internasional Tahun 1982 yang telah diratifikasi dengan Undang-Undang Nomor 17 Tahun 1985 tentang Pengesahan United Nations Convention on the Law of the Sea. ${ }^{2}$ Pasal tersebut secara tegas mengatur tentang status hukum perairan kepulauan, ruang udara di atas perairan kepulauan dan dasar laut serta tanah dibawahnya. ${ }^{3}$ Kedaulatan wilayah yang bersifat complete and exclusive sejauh ini diatur dalam Undang-Undang Nomor 1 Tahun 2009 Tentang Penerbangan, tetapi tidak secara spesifik mengatur mengenai batas ruang udara Indonesia yang berdaulat, baik secara vertikal maupun horizontal. Ruang udara nasional (national airspace) suatu negara sepenuhnya tertutup bagi pesawat udara asing, baik sipil maupun militer, sehingga harus dengan izin negara kolong terlebih dahulu, baik melalui perjanjian bilateral ataupun perjanjian multilateral, sehingga ruang udara nasional suatu negara dapat dilalui oleh pesawat udara asing. ${ }^{4}$ Sifat tertutup yang sedemikian itu dapat dipahami mengingat ruang udara sebagai media gerak yang sangat rawan apabila ditinjau dari segi pertahanan dan keamanan negara kolong. Serangan- serangan dengan menggunakan pesawat udara banyak memiliki keuntungan dan kemudahan yang dapat mengekspolitasi kerawanan suatu ruang udara, seperti sifatnya yang cepat (speed), jangkauan (range) yang luas, mendadak (surprise), penyusupan (penetration) yang dapat dilakukan dengan optimal. ${ }^{5} \mathrm{Hal}$ inilah yang mendorong setiap negara mengenakan standar penjagaan ruang udara nasionalnya secara ketat dan kaku. Penerbangan antar negara sepenuhnya diatur melalui Bilateral Air Transport Agreement (BATA). Tanpa BATA, negara tidak dapat menyelenggarakan jasa angkutan udara menuju suatu negara. BATA sendiri merupakan salah satu bentuk implementasi kedaulatan negara di ruang udara yang bersifat complete and exclusive ${ }^{6}$ di tengah tantangan globalisasi, seperti liberalisasi penerbangan (Open Sky Policy). Merujuk kepada Open Sky Policy, kebijakan ini memperbolehkan perusahaan jasa angkutan udara untuk membuat keputusan pada rute, kapasitas, harga, dan pilihan yang beragam dalam kegiatan penerbangan.
\end{abstract}

Kata Kunci: Tata Ruang Udara; Open Sky Policy; Interdependent Airspace Governance

Abstract. Indonesia as an archipelago state has a national airspace of 5,180,053 $\mathrm{km}^{2}$. Indonesia's airspace is located in a strategic position between the continents of Asia and Australia which makes Indonesia one of the busiest air routes in the world. Therefore, the management of air space is a vital matter that must be emphasized through various legal instruments. The sovereignty of Indonesian air space is affirmed in Article 49 paragraph (2) of the 1982 International Law of the Sea Convention which was ratified by Law Number 17 of 1985 concerning Ratification of the United Nations Convention on the Law of the Sea. This article explicitly regulates the legal status of archipelagic waters, air space over archipelagic waters and the seabed as well as the land below. So far, territorial sovereignty that is complete and exclusive is regulated in Law Number 1 of 2009 concerning Aviation, but it does not specifically regulate the boundaries of Indonesia's sovereign air space, either vertically or horizontally. The national airspace of a country is completely closed to foreign aircraft, both civilian and military, so it must be with the permission of the underworld, either through bilateral agreements or multilateral agreements, so that a country's national air space can be traversed by foreign aircraft. Such closed nature can be understood considering that air space is a very vulnerable medium of movement when viewed from the point of view of under-state defense and security. Attacks using aircraft have many advantages and conveniences that can exploit the vulnerability of an air space, such as its fast (speed), wide range, surprise, optimal penetration. This is what prompts each country to adopt its national airspace protection standards which are strict and

${ }^{1}$ Badan Informasi Geografi, "Badan Informasi Geografi Serahkan Peta NKRI Kepada Kemenkokesra”, Badan Informasi Geografi, <http://www.bakosurtanal.go.id/berita- surta/show/big-serahkan-peta-nkri-kepada-kemenkokesra>, diakses pada tanggal 20 September 2017 pukul 17.23WIB.

2 Adi Kusumaningrum, 2012, Prinsip Cabotage Dalam Industri Penerbangan Indonesia DiEra Asian Single Aviation Market 2015, Universitas Brawijaya Press, Malang, hlm.9.

${ }^{3}$ Ibid.

${ }^{4}$ Dinas Hukum TNI AU, 2014, “Optimalisasi Pengaturan / Pengelolaan Ruang Udara Nasional Untuk Pertahanan Dan Keamanan Negara", Pustaka Tata Ruang dan Pertahanan, Jakarta, hlm.8.

${ }^{5}$ Ibid.

${ }^{6}$ Harry Purwanto, "Implikasi ASEAN Open Sky Policy terhadap Kedaulatan Negara diRuang

Udara”, 2016, Yogyakarta, hlm. 44. 
Wahyu Beny Mukti Setiyawan et al, Urgensi Penerapan Interdependent Airspace Governance Untuk Optimalisasi Tata Kelola Ruang Udara Nasional Sebagai Antisipasi Open Sky Policy

rigid. Flights between countries are fully regulated through the Bilateral Air Transport Agreement (BATA). Without BATA, the state cannot provide air transportation services to a country. BATA itself is a form of implementation of state sovereignty in air space that is complete and exclusive in the midst of globalization challenges, such as aviation liberalization (Open Sky Policy). Referring to the Open Sky Policy, this policy allows air carriers to make decisions on routes, capacities, prices and various options for flight activities.

Keywords: Air Space; Open Sky Policy; Interdependent Airspace Governance

\section{PENDAHULUAN}

Dengan adanya kebijakan Open Sky, akan semakin memudahkan mobilitas penduduk di seluruh kawasan Asia Tenggara yang berdampak langsung pada perekonomian negara- negara Asia Tenggara, baik itu dari segi pariwisata, ekspor-impor, pengiriman jasa kargo dan lainnya. ${ }^{7}$ Selain itu, masih terdapat beberapa aspek yang belum diatur secara jelas dalam peraturan hukum sekarang, seperti (1) Batas vertikal dan horisontal dari ruang udara nasional; (2) Pengaturan pengamanan ruang udara negara; (3) Pengaturan tentang kewenangan penyidik di luar Polisi dan PPNS terkait pelanggaran ruang udara; dan tindak pidana di/melalui ruang udara; (4) Pemanfaatan ruang udara untuk kepentingan internasional (misal ALKI); (5) Pengendalian kegiatan di ruang udara di atas wilayah konflik; (6) Pengaturan pengelolaan ruang udara untuk kepentingan Iptek;dan (7)Pengaturan olahraga dan wisata dirgantara. ${ }^{8}$ Untuk beberapa aspek tersebut, tentu diperlukan kajian yang lebih mendalam terutama mengenai diperlukannya regulasi dalam bentuk undang- undang untuk menjawab aspek permasalahan yang telah diuraikan sebelumnya. Berbagai aspek yang belum diatur secara tuntas tersebut, sebenarnya sudah terakomodasi dalam Rancangan Undang-Undang tentang Pengelolaan Ruang Udara Nasional (RUU PRUN) yang merupakan inisiatif dari DPR sendiri yang kemudian memasukkan RUU tersebut ke dalam Program Legislasi Nasional (Prolegnas) Jangka Menegah untuk periode 2010-2014. Akan tetapi sampai dengan saat ini, RUU tersebut belum pernah diajukan DPR sebagai prioritas tahunan. ${ }^{9}$ Ruang lingkup dari RUU PRUN meliputi; fungsi ruang udaranasional; perencanaan; pemanfaatan; pengembangan; pengendalian; pembinaan; koordinasi; kerja sama; sistem informasi; pembiayaan; pengawasan; peran serta masyarakat; penegakan hukum di ruang udara nasional; dan penjelasan umum. ${ }^{10}$ Selain dari masih adanya kekosongan hukum terkait tata kelola ruang udara nasional, masih terdapat permasalahan lainnya yang akan menghambat upaya pemerintah untuk menegakkan kedaulatannya di ruang udara nasional. Permasalahan tersebut terdapat pada masih kurangnya koordinasi dari berbagai lembaga negara, seperti Lembaga Penyelenggara Pelayanan Navigasi Penerbangan Indonesia/AirNavigation (AirNav), Kementerian Agraria dan Tata Ruang (ATR), TNI Angkatan Udara (TNI AU), dan Lembaga Penerbangan dan Antariksa Nasional (LAPAN) dalam upaya mengantisipasi implikasi negatif dari adanya Open Sky Policy.

Belum siapnya infrastruktur fisik, instrumen hukum, seperti regulasi, kebijakan, maupun koordinasi kelembagaan justru menjadi tantangan tersendiri bagi pemerintah. Oleh karena itu, upaya untuk mempersiapkan instrumen hukum secara komprehensif menjadi suatu urgensi tersendiri dalam upaya penegakan kedaulatan ruang udara nasional di tengah arus liberalisasi penerbangan dalam penyelenggaraan Open Sky Policy.

\section{METODE}

Pendekatan yang penulis gunakan dalam penelitian ini adalah pendekatan Perundang - undangan (statute approach) dan Konsep (conceptual approach). Pendekatan ini dilakukan dengan menelaah semua peraturan perundang - undangan yang bersangkut paut dengan permasalahan (isu hukum) yang sedang dihadapi. Pendekatan perundang - undangan ini misalnya dilakukan dengan mempelajari konsistensi/kesesuaian antara Undang - Undang Dasar dengan Undang - Undang,

Atau antara Undang-Undang yang satu dengan Undang-Undang yang lain. Kemudian beranjak dari pandangan pandangan dan doktrin-doktrin yang berkembang di dalam ilmu hukum. Pendekatan ini menjadi penting sebab pemahaman terhadap pandangan/doktrin yang berkembang dalam ilmu hukum dapat menjadi pijakan untuk membangun argumentasi hukum ketika menyelesaikan isu hukum yang dihadapi. Pandangan/doktrin akan memperjelas Ide ide dengan memberikan pengertian-pengertian hukum, konsep hukum, maupun asas hukum yang relevan dengan permasalahan.

${ }^{7}$ Oki Pramana Putra, 2012, “Upaya Indonesia Dalam Menghadapi Implementasi Asean OpenSky Tahun 2015”, Universitas Riau Press, Riau, hlm.6.

${ }^{8}$ Ibid.

${ }^{9}$ Wicipto Setiadi, "Pemetaan Pengaturan Pengelolaan Ruang Udara Di Indonesia",

$<$ https://id.scribd.com/presentation/222795252/Pemetaan-Pengaturan-Pengelolaan-Ruang-Udara-di-Indonesia>, diakses tanggal

20 September 2017 pukul 11.30 WIB.

${ }^{10}$ Supancana, Loc.cit. 
Wahyu Beny Mukti Setiyawan et al, Urgensi Penerapan Interdependent Airspace Governance Untuk Optimalisasi Tata Kelola Ruang Udara Nasional Sebagai Antisipasi Open Sky Policy

\section{HASIL DAN PEMBAHASAN}

\section{Open Sky Policy Dalam Kaitannya Dengan Tata Kelola Ruang Udara Nasional}

Dalam prinsip kedaulatan yang mutlak dan penuh atas ruang udaranya, suatu negara berhak untuk mengelola ruang udaranya sehingga bebas dari intervensi negara lain. ${ }^{11}$ Prinsip kedaulatan tersebut setidaknya juga diakuidalam perjanjian Multilateral, seperti Pasal 1 ayat (1) ASEAN Multilateral Agreement on Air Services yang mendukung kebijakan ASEAN Open Sky yang menyatakan bahwa negara-negara peserta perjanjian tersebut telah meratifikasi Konvensi Chicago 1994 dan konvensi tersebut masih berlaku secara efektif bagimereka. ${ }^{12}$ Jika Konvensi Chicago 1994 masih berlaku secara efektif, maka Indonesia harus tetap pada prinsipnya untuk mempertahankan prinsipnya dengan mengedepankan asas resiprositas pada kebijakan ASEAN Open Sky. ${ }^{13}$ Penerapan asasresiprositas merupakan salah satu usaha Indonesia untuk bisa mandiri dalam hal pengelolaan ruang udaranya.

Putusan Mahkamah Konstitusi pun telah berketetapan terkait pengertian Hak Menguasai Negara yang mencakup lima pengertian. Dalam Hak Menguasai Negara tersebut, negara dapat merumuskan kebijakan (beleid), melakukan pengaturan (regelendaad), melakukan pengurusan (bestuurdaad), melakukan pengelolaan (beheerdaad) dan melakukan pengawasan (toezicht houdendaad) untuk tujuan sebesar-besarnya kemakmuran rakyat. ${ }^{14}$ Kelima Hak Menguasai Negara tersebut merupakan tafsir Mahkamah Konstitusi dalam pengertian penguasaan negara yang dimaksud dalam Pasal 33 ayat (3) Undang-Undang Dasar Republik Indonesia Tahun 1945. ${ }^{15}$

\section{Implementasi Open SkyPolicy}

Perjanjian yang kemudian menjadi titik tolak dari ASEAN Open Sky Policy adalah ASEAN Multilateral Agreement on the Full Liberalisation of Air Freight Services (MAFLAFS), ASEAN Multilateral Agreement on Air Services (MAAS), dan ASEAN Multilateral Agreement on the Full Liberalisation of Passenger Air Services (MAFLPAS). Setelah meratifikasi perjanjian multilateral tersbeut, Indonesia melaksanakan ASEAN Open Sky Policy secara bertahap. Tahap pertama Open Sky Policy dilaksanakan terhitung pada 30 Juni 2010. Sementara tahap kedua dimulai pada 30 Juni 2013. Pada tahap pertama dan kedua, kesepakatan ASEAN Open Sky Policy mengikat negaranegara yang sudah menyatakankesiapannya, seperti Brunei Darusalam, Malaysia, Singapura, dan Thailand. Sedangkan bagi negara Anggota ASEAN lainnya yang belum sepenuhnya siap, seperti Indonesia, Filipina, dan negara lainnya, perjanjian ASEAN Open Sky Policy akan diberlakukan secara bertahap, bukan Full Open Sky Policy. Untuk itu, negara- negara tersebut diberi kelonggaran untuk mempersiapkan diri sampai sebelum 30 Juni 2015. Maka dapat disimpulkan bahwa terhitung 30 Juni 2015 keseluruhan negara anggota ASEAN wajib tunduk pada ASEAN Open Sky Policy. ${ }^{16}$

Praktek Open Sky Policy nantinya akan membentuk liberalisasi dalam penggunaan sumber daya alam Indonesia berupa udara, sehingga melalui perjanjian kerja sama tersebut, ruang udara dalam teritorial Indonesia dapat digunakan negara lain sebagai implementasi liberalisasi penerbangan.

\section{Implikasi Open Sky Policy bagi Kedaulatan Ruang Udara Indonesia}

Pelaksanaan Open Sky Policy, dalam lingkup regional seperti ASEAN Open Sky Policy menjadi dilema bagi Indonesia. Walaupun di satu sisi menawarkan perkembangan ekonomi lewat terintegrasinya konektivitas penerbangan yang akan terwujud lewat pemberlakuan ASEAN Open Sky Policy. Namun, di satu sisi ada bagian yang mengancam kedaulatan negara. Di balik tawaran yang menggiurkan tersebut, tentu terdapat kepentingan masing-masing negara yang menjadi penggagas dari kebijakan tersebut.

\section{Kesiapan Instrumen Hukum Di Indonesia Menghadapi Open Sky Policy}

Setelah meratifikasi Open Sky, baik melalui perjanjian bilateral ataupun perjanjian multilateral, seperti ASEAN Open Sky Policy, Indonesia mau tidak mau harus mempersiapkan diri dalam rangka menyambut liberalisasi

\footnotetext{
${ }^{11}$ Ketentuan mengenai kedaulatan juga diatur dalam Pasal 2 Ayat (2) Konvensi Hukum Laut PBB 1982 yang telah diratifikasi Indonesia dengan Undang-Undang Nomor 17 Tahun 1985 tentang Pengesahan United Nations Convention on the Law of the Sea (Konvensi Perserikatan Bangsa- Bangsa tentang Hukum Laut), menentukan bahwa kedaulatan negara meliputi ruang udara di atas laut teritorial serta dasar laut dan tanah di wilayahnya.

${ }^{12}$ Vide Pasal 1 ayat (1) ASEAN Multilateral Agreement on Air Services (ASEAN MAAS).

${ }^{13}$ K. Martono dan Ahmad Sudiro, Op. cit., hlm. 51.

${ }^{14}$ Kuntana Magna dkk. “Tafsir Mahkamah Konstitusi Atas Pasal 33 Undang-Undang Dasar Republik Indonesia Tahun 1945 (Putusan MK Mengenai Judicial Review Undang-Undang No. 7 Tahun 2004, Undang-Undang Nomor 22 Tahun 2001, dan Undang-Undang Nomor 20 Tahun

2002)", Jurnal Konstitusi, Volume 7, Nomor 1, Februari 2010.

${ }^{15}$ Ibid.

${ }^{16}$ Harry Purwanto, Op.cit.,. hlm. 68.
} 
Wahyu Beny Mukti Setiyawan et al, Urgensi Penerapan Interdependent Airspace Governance Untuk Optimalisasi Tata Kelola Ruang Udara Nasional Sebagai Antisipasi Open Sky Policy

penerbangan di ruang udaranasionalnya. ${ }^{17}$ Peran pemerintah dalam mengelola ruang udara nasional, lewat regulasi, kebijakan, dan kelembagaan yang dibuat, bisa menjadi tolok ukur kesiapan Indonesia dalam menghadapi Open Sky Policy.

\section{Belum Adanya Regulasi Hukum Yang Jelas dan Spesifik Terkait Tata Kelola Ruang UdaraNasional}

Melalui regulasi hukum, pemerintah mendapatkan legitimasinya untuk mengatur dan mengelola ruang udara nasional untuk kemakmuran dan kepentingan rakyat, sebagaimana diamanatkan dalam Pasal 33 ayat (3) UUD 1945.

Regulasi hukum yang dikeluarkan oleh Pemerintah pun masih belum jelas, spesifik, dan komprehensif mengatur kewenangan pemerintah untuk mengelola ruang udara nasionalnya. Undang-undang yang memiliki irisan terhadap ruang udara nasional, seperti Undang-Undang Republik Indonesia Nomor 26 Tahun 2007 tentang Penataan Ruang (UU tentang Penataan Ruang), Undang-Undang Republik Indonesia Nomor 43 Tahun 2008 tentang Wilayah Negara (UU tentang Wilayah Negara), dan Undang-Undang Republik Indonesia Nomor 1 Tahun 2009 tentang Penerbangan (UU tentang Penerbangan).

Di dalam UU tentang Penerbangan, terdapat beberapa bagian yang mulai mengarah kepada kewenangan pemerintah dalam mengelola ruang udara nasionalnya, yakni pada Pasal 6 dan Pasal 90 yang berbunyi:

"Dalam rangka penyelenggaraan kedaulatan negara atas ruang udara Negara Kesatuan Republik Indonesia, Pemerintah melaksanakan wewenang dan tanggung jawab pengaturan ruang udara untuk kepentingan penerbangan, perekonomian nasional, pertahanan dan keamanan negara, sosial budaya, serta lingkungan udara." ${ }^{18}$ (Pasal 6).

"(1) Pembukaan pasar angkutan udara menuju ruang udara tanpa batasan hak angkut udara (Open Sky) dari dan ke Indonesia untuk perusahaan angkutan udara niaga asing dilaksanakan secara bertahap berdasarkan perjanjian bilateral atau multilateral dan pelaksanaannya melalui mekanisme yang mengikat para pihak. (2) Perjanjian bilateral atau multilateral sebagaimana dimaksud pada ayat (1) dibuat sesuai dengan ketentuan peraturan perundang-undangan dan mempertimbangkan kepentingan nasional berdasarkan prinsipkeadilan dan timbal balik." ${ }^{19}$ (Pasal90).

Dari ketiga peraturan perundang-undangan yang merupakan peraturan hukum resmi tersebut, didapati terjadinya kekosongan hukum yang menyebabkan tidak adanya jaminan kepastian hukum atas tindakan maupun kewenangan pemerintah dalam mengelola ruang udara nasionalnya. ${ }^{20}$

Namun, berdasarkan uraian tersebut, didapati suatu hal yang penting, yakni perlu adanya regulasi hukum, dalam hal ini peraturan perundang-undangan yang secara khusus menjadi payung hukum bagi tindakan maupun kewenangan pemerintah dalam mengelola ruang udara nasionalnya. Hal ini terlihat dari amanat yang disampaikan dalam Pasal 6 ayat (5) UU tentang PenataanRuang.

\section{Wacana Rancangan Undang-Undang Pengelolaan Ruang Udara Nasional (RUUPRUN)}

Wacana terkait Rancangan Undang-Undang Pengelolaan Ruang Udara Nasional (RUU PRUN) bisa dikatakan sebagai kemajuan yang progresif dalam langkah pemerintah untuk menegakkan kedaulatan udara lewat tugas dan kewenangannya dalam mengelola ruang udara nasionalnya. Wacana ini tidak lepas dari beberapa urgensi perlunya payung hukum yang jelas mengenai tugas dan kewenangan pemerintah dalam mengelola ruang udara nasionalnya,seperti: ${ }^{21}$

1. Amanat dalam Pasal Pasal 6 ayat (5) UU tentang Penataan Ruang yang menyatakan bahwa pengelolaan ruang udara seharusnya diatur dengan Undang-Undang sendiri. Oleh karena itu, RUU PRUN diharapkan menjadi jawaban atas amanat dalam Pasal Pasal 6 ayat (5) UU tentang Penataan Ruang dan dapat menjadi payung hukum yang jelas dan spesifik dalam membahas tugas dan kewenangan pemerintah untuk mengatur dan mengelola ruang udaranasionalnya.

2. Adanya kekosongan hukum dalam aspek-aspek tertentu mengenai pengelolaan ruang udara nasional yang belum diatur secara jelas, spesifik, dan komprehensif.

${ }^{17}$ Ferdi, 2015, "Implikasi Yuridis Dari Ratifikasi Piagam Asean Terhadap Perdagangan Jasa Penerbangan Di Indonesia Dalam Rangka Menuju Asean Economic Community Tahun 2015”, Jurnal Ilmu Hukum, Volume 5, Februari, 2016.

${ }^{18}$ Vide Pasal 6 Undang-Undang Republik Indonesia Nomor 1 Tahun 2009 tentang Penerbangan.

${ }^{19}$ Vide Pasal 90 Undang-Undang Republik Indonesia Nomor 1 Tahun 2009 tentang Penerbangan.

${ }^{20}$ Supancana, Loc.cit..

${ }^{21}$ Ibid. 
3. Terdapat beberapa aspek yang masih belum diatur secara tuntas dalam regulasi atau peraturan hukum sekarang, seperti (1) Belum jelasnya batas vertikal dan horizontal dari ruang udara nasional; (2) Pengaturan pengamanan ruang udara negara; (3) Pengaturan tentang kewenangan penyidik di luar Polisi dan PPNS terkait pelanggaran ruang udara; (4) Tindak pidana di/melalui ruang udara; (5) Pemanfaatan ruang udara untuk kepentingan internasional (misalnya Arus Laut Kepulauan Indonesia); (6) Pengendalian kegiatan di ruang udara di atas wilayah konflik; (7) Masalah Flight Information Region; (8) Pengaturan tentang kewenangan daerah dalam pengaturan ketinggian bangunan (bangunan tinggi dan menara); (9) Pembagian kewenangan Pusat dan Daerah dalam pengelolaan ruangudara; (10) Pengaturan tentang sumber energiangin; (11) Pengaturan pengelolaan ruang udara untuk kepentingan Ilmu pengetahuan dan teknologi; (12) Pengaturan olah raga dan wisata dirgantara.

Oleh karena berbagai alasan yang menjadi urgensi tersebut, RUU PRUN perlu untuk segera disahkan menjadi undang-undang agar melengkapi peraturan hukum yang sudah ada sekarang sekaligus menjadi payung hukum yang menjamin tindakan pemerintah untuk mengelola ruang udara nasional. Di mana ruang udara nasional tersebut, tidak saja terbatas pada manajemen penerbangan saja, tetapi mewadahi seluruh potensi ruang udara nasional secarakomprehensif.

\section{Lembaga Negara yang Masih Bekerja Secara Otonom}

Pemerintah membentuk atau mengoordinasikan tugas berbagai lembaga negara, seperti AirNav Indonesia, TNI Angkatan Udara, Kementerian Agraria dan Tata Ruang (ATR), dan Badan Penerbangan dan Antariksa Nasional (LAPAN).

Berdasarkan tinjauan Penulis, sekalipun terdapat banyak badan yang bergerak pada sektor tata kelola ruang udara, tetapi ada beberapa kelemahan yang menyebabkan keberadaan maupun kinerja badan yang ada belum optimal, termasuk tidak efektifnya koordinasi kelembagaan bentukan pemerintah, seperti:

1. Dibentuk tanpa memberikan bagaimana masalah liberalisasi penerbangan dikoordinasikan, terutama mengenai pengelolaan ruang udara nasional;

2. Tidak adanya kesamaan visi antar badan negara, terutama terkait upaya optimalisasi ruang udara nasional sebagai langkah antisipatif Open Sky Policy;

3. Dalam pelaksanaan Tupoksinya, keempat badan tersebut seolah berjalan sendiri-sendiri (otonom). Padahal diperlukan adanya koordinasi yang sinergis antar badan tersebut untuk mempermudahkan upaya pemerintah dalam pengelolaan ruang udara nasional sebagai langkah untuk menegakkan kedaulatan udara nasional

\section{SIMPULAN}

Berdasarkan uraian pembahasan atas rumusan masalah di atas, Penulis mengambil kesimpulan sebagai berikut:

1. Keikutsertaan Indonesia dalam Open Sky Policy yang dinilai masih prematur, berimplikasi terhadap ketidaksiapan infrastruktur fisikdan instrumen hukum terkait tata kelola ruang udara nasional sebagai langkah mengantisipasi liberalisasi penerbangan yang akan mengancam kedaulatan negara atas ruangudara.

2. Instrumen hukum, seperti regulasi, kebijakan, dan kelembagaan yang ada dinilai belum siap dan mampu untuk menghadapi Open Sky Policy di tengah upaya untuk menegakkan kedaulatan negara di ruang udara melalui optimalisasi tata kelola ruang udara nasional. Belum adanya payung hukum yang jelas, spesifik, dan komprehensif terkait tata kelola ruang udara dan masih kurang koordinasinya lembaga negara yangberfokus pada pengelolaan tata ruang udara nasional menjadi alasan kunci dari ketidaksiapan instrumen hukum Indonesia mengantisipasi arus liberalisasi penerbangan Open SkyPolicy.

3. Interdependent Airspace Governance sebagai sebuah sistem kerja pengelolaan ruang udara nasional yang terintegrasi memiliki keunggulan yangmendukung kedaulatan negara atas ruang udara nasional dengan mekanisme kesatuan koordinasi yang sinergis antar lembaga negara yang berfokus pada pengelolaan tata ruang udara nasional sebagai upaya efektif dan efisien menanggulangi ketidaksiapan infrastruktur fisik dan instrumen hukum terkait tata kelola ruang udara nasional sebagai langkah mengantisipasi liberalisasi penerbangan yang akan mengancam kedaulatan negara atas ruang udara.

\section{DAFTAR PUSTAKA}

\section{Buku}

Kurnia, Mahendra P., 2011, Hukum Kewilayahan Indonesia: Harmonisasi Hukum Pengembangan Kawasan Perbatasan NKRI Berbasis Teknologi Geospasial, Universitas Brawijaya Pres, Malang.

Kusumaatmaja, Mochtar, 2003, Konsepsi Hukum Negara Nusantara pada Konferensi Hukum Laut III, Bandung, Pusat Studi Wawasan Nusantara.

Kusumaningrum, Adi, 2012, Prinsip Cabotage Dalam Industri Penerbangan Indonesia Di Era Asian Single Aviation Market 2015, Universitas Brawijaya Press, Malang. 
Wahyu Beny Mukti Setiyawan et al, Urgensi Penerapan Interdependent Airspace Governance Untuk Optimalisasi Tata Kelola Ruang Udara Nasional Sebagai Antisipasi Open Sky Policy

Martono, K., 2007, Pengantar Hukum Udara, Nasional, dan Internasional, Raja Grafindo Persada, Jakarta.

Martono, K., dan Sudiro, Ahmad, 2012, Hukum Udara Nasional dan Internasional Publik, Jakarta Rajawali Press,Jakarta.

\section{Artikel dan Jurnal}

Dinas Hukum TNI AU, 2014, "Optimalisasi Pengaturan / Pengelolaan Ruang Udara Nasional Untuk Pertahanan Dan Keamanan Negara", Pustaka Tata Ruang dan Pertahanan, Jakarta.

Ferdi, 2015, "Implikasi Yuridis Dari Ratifikasi Piagam Asean Terhadap Perdagangan Jasa Penerbangan Di Indonesia Dalam Rangka Menuju Asean Economic Community Tahun 2015”, Jurnal Ilmu Hukum, Volume 5, Februari, 2016.

Kementerian Perhubungan, 2012, Majalah Kementerian Perhubungan. "Pasar Penerbangan Bergeser dari Atlantik ke Asia Pasifik”, Transmedia, Edisi 5.

Magna, Kuntana, dkk., "Tafsir Mahkamah Konstitusi Atas Pasal 33 Undang- Undang Dasar Republik Indonesia Tahun 1945 (Putusan MK Mengenai Judicial Review Undang-Undang No. 7 Tahun 2004, Undang-Undang Nomor 22 Tahun 2001, dan Undang-Undang Nomor 20 Tahun 2002)”, Jurnal Konstitusi, Volume 7, Nomor 1, Februari 2010.

\section{Karangan/Esai}

Purwanto, Harry, "Implikasi ASEAN Open Sky Policy terhadap Kedaulatan Negara di Ruang Udara", 2016, Yogyakarta.

\section{Internet}

Badan Informasi Geografi, "Badan Informasi Geografi Serahkan Peta NKRI Kepada Kemenkokesra", Badan Informasi Geografi, http://www.bakosurtanal.go.id/berita-surta/show/big-serahkan-peta-nkri- kepadakemenkokesra, diakses pada tanggal 20 September 2017 pukul 17.23 WIB.

Supancana, "Kilas Balik, Urgensi Dan Proses Penyusunan Naskah Akademis Dan Rancangan Undang-Undang Pengelolaan Ruang Udara Nasional (RUU- PRUN)", https://id.scribd.com/presentation/236684960/Kilas-BalikUrgensi-dan-Proses-Penyusunan-Naskah-Akademis-dan-Rancangan-Undang-Undang-Pengelolaan-RuangUdara-Nasional-RUU-PRUN, diakses tanggal 13 September 2020 pukul 15.20 WIB.

TNI Angkatan Udara, Tugas Pokok dan Fungsi KOHUDNAS, http://www.kohanudnas.mil.id/publik/content?id=48\&menu=KOHANUDNAS-Tugas-KOHANUDNAS, diakses tanggal 12 September 2020 pukul 19.13.

United States Departement of State, "Open Skies Agreement", https://www.state.gov/e/eb/rls/othr/2006/22281.html, diakses pada 14 September 2020 pukul 19.30. 